\title{
pasiafic
}

Asia Pacific Viewpoint, Vol. 52, No. 3, December 2011

ISSN 1360-7456, pp236-246

\section{Surfers of the ocean waves: Change management, intersectoral migration and the economic development of small island states}

\author{
Godfrey Baldacchino \\ Island Studies Program, University of Prince Edward Island, 550, University Avenue, Charlottetown, PE, Canada, C1A 4P3. \\ Email: gbaldacchino@upei.ca
}

\begin{abstract}
This paper argues that there is a need to better acknowledge and problematise the manner in which individuals, households, organisations and governments in small island jurisdictions develop mechanisms that allow them to exploit the benefits, and/or minimise the losses, of episodic economic lurches. A 'strategic flexibility' approach is proposed to explain how actors practise intersectoral migration: cleverly shifting focus, interest and scope, not just out of necessity (reactively) but in 'smelling' promising opportunities (proactively). In a scenario where change is taken as a given, managing and coping with such change become the hallmarks of economic survival: just like surfers handling the ocean swell.
\end{abstract}

Keywords: intersectoral migration, MIRAB, PROFIT, small islands states, strategic flexibility, vulnerability

\section{Introduction: Scripted jurisdictions}

Small island states come across as those jurisdictions that are the easiest to conceptualise and script as weak and vulnerable; their very smallness, self-evident scale and presumed manageability make them tempting projects to essentialise and classify. Their remoteness, their smaller populations, the open nature of their economies, their proneness to environmental mishaps, their limited land area and resource bases, their lack of industrial clout, the higher costs involved in doing both private business and government ... all these and other features collectively make them highly suited to the discourse of vulnerability, of a structural incapacity to organise their own future (e.g. Alesina and Spolaore, 2003; Winters and Martins, 2004). Such a discourse - so readily visible from a quick literature scan, punctuated as it is by references to 'problems', 'dangers', 'dilemmas' and notions of 'paradise lost' - has of course become more politically correct since the acceptance of 'small states' and 'small island developing states' (SIDS) as legitimate policy

(C) 2011 The Author

Asia Pacific Viewpoint (C) 2011 Victoria University of Wellington categories: the first by the Commonwealth Secretariat since 1985 and the second by the United Nations and the World Bank since 1992 (Harden, 1985; Easterly and Kraay, 2000: 2013). This transition has happened parallel to the recognition of the environmental dangers posed by global warming and sea-level rise: note the setting up of the Alliance of Small and Island States (now with 42 member states) in 1991; and the strong visibility achieved by the SIDS lobby in recent climate change negotiations. 'Saving small island states from sinking' is a current and probably the most highly visible policy item on the international agenda that features small island states today (e.g. Nath et al., 2010). Of course, 'small states' themselves (most of which are islands anyway), however defined - but significantly present among the world's sovereign states - have been pushing such an agenda as it allows their concerns to remain somehow present and visible on the international relations table in the postcold war scenario. ('Non-conventional security threats' is probably a distant, second agenda item of relevance.) 
There is, concurrently, a stubborn disposition, traceable certainly to Margaret Mead (1930), to treat islands as small and easy items of analysis. So much talk about small island units as being 'convenient microcosms' or 'laboratories' of/for larger polities betrays a naive misunderstanding of the specificities of small island economies and of the complex nature of their own assemblages and articulations. Perhaps mainly for these reasons, it has been easy to classify small island economies as hyperspecialised in a single export crop or narrow revenue stream - whether it is selling nickel, welcoming tourists or creaming in aid and remittances - with little appreciation for the rest of the economy, in both the formal and the informal sectors, and its inherent diversity. Such gross simplifications need to make way for a more nuanced understanding of the characteristics of small economies, as suggested further below.

\section{Strident expressions of vulnerability}

There are some clear differences among the meteorology, the politics and the economics of small island vulnerability. Environmental disasters can and do happen: and the way these manifest themselves on small island states especially compact, non-archipelagic ones - is quite distinct from other territories. When such disasters do strike small island states, their impacts are more likely to be sudden, rapid and total; the whole island resident population is likely to be affected; devastation of infrastructure is extensive; and there is no domestic 'hinterland' to which people can flee or take refuge before the event (assuming that they have enough early notice) or from which to command support and resources after the event: any such assistance has to come from overseas/ other countries.

The politics of vulnerability are somewhat different. Here, proponents (e.g. Briguglio, 1995) have been arguing that the relatively high levels of gross domestic product per capita registered by small island states nevertheless conceal a fragile base, one that can easily be wiped out: in a flash by a hurricane; rapidly by a decline in the demand and the world market price of a specific commodity; or slowly but surely with creeping sea-level rise. About the latter, the international community, especially the richer and the most polluting nations, is being encouraged to see themselves as responsible for the increasingly tragic predicament of small island communities. Some financial payments have been extracted; but the notion of environmental refugees - which would then grant asylum rights to small island residents seriously threatened by sea level rise - remains stalled (e.g. Bates, 2002).

The economics of small islands is much less constrained by political borders: the invariably open nature of island economies does not simply mean that they are committed to, and compromised by, very high levels of importation and (preferably as high levels of) exportation of goods and services; but also that the physical disposition of their populations is similarly transterritorial. The various papers published in Asia Pacific Viewpoint (and its forerunner, Pacific Viewpoint) since 1985, explaining the rationale of aid and remittance transfers to small island economies and their citizens, have been seminal in arguing that a proper assessment of a small island economy cannot be restricted to domestic production and consumption. What would otherwise be defined as 'externalities' are simply crucial to and at the heart of the liveability of small island residents (e.g. Tisdell, 1993). Denigrating such practices as 'unsustainable', 'artifi-

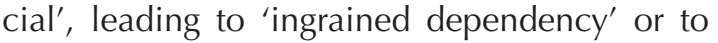
'consumption maximisation' simply betrays an obsession with national politico-economic borders, some mythical sense of appropriate and responsible market behaviour, and a stymied concern with domestic economic transactions that hardly reflects the situation 'on the ground' (e.g. Baldacchino, 1993; Poirine, 1998). Indeed, the large number of sub-national (often small) island jurisdictions today is clear testimony that there is a strong economic case for nonindependence when the status quo thus guarantees lifelines to richer and larger polities for the small and islanded (Baldacchino and Milne, 2008; Baldacchino, 2010). Meanwhile, there remains no compelling empirical basis for claiming the inherent economic vulnerability of small island states and territories. Paradoxically, the openness of small economies to international trade, with its associated volatility, can be a source of strength rather than a weakness for small economies, obliging these to strive for 
competitiveness in regional or international markets and niches, while largely preventing them from collapsing into anarchy and protectionism (Alesina and Spolaore, 2003; Armstrong and Read, 2003, 2004: 214-218).

\section{Disposition towards change}

Now, to this emergent realisation of the inherent trans-territorial nature of a small island economy, one needs to add a second acknowledgement: that of the inherent disposition towards change. Once this 'turn' is achieved, one can more profitably shift one's sights to how such change is managed within the constraints and circumstances that present themselves.

From a crudely rational scientific perspective, the dynamics of economic activity are inversely proportional to the population size. Economic activity is a sum total of the actions and transactions of individual actors; and having fewer individual actors in a particular population base means that the implications of what any one of these actors does, or will not do, will loom much larger in the national statistics. The transaction involved in, say, purchasing a new airplane for the national air carrier, or a new vessel for the national coast guard service, may not be a remarkable transaction in the accounts of a large country; it is, however, more likely to be visible as a spike in the national accounts of a small state. Similarly, the opening of a garment factory employing 200 people is no big deal to most territories, but it could significantly reduce unemployment in a smaller jurisdiction. Of course, the converse applies as well: the closure of a fish-processing plant employing 200 people could be seen as a national disaster.

Small economies are characterised by the sudden, rapid and total consequences of booms and busts, peaks and troughs, each of which may thus be considered as assuming crisis proportions. 'Approach to a single isolated problem leads extraordinarily rapidly to all parts of the complex, more quickly and completely than we have observed elsewhere' (Bowen-Jones, 1972: 59). A comment on epidemics is illustrative: in island communities, epidemics occur less frequently; but they affect a greater proportion of the resident population, and with faster speed, when they do (Dommen, 1980: 926). Meanwhile, Carse (1998) demonstrates graphically how, over time, annual changes in the gross national product (GNP) of the small and open economy of the Isle of Man lurch much more dramatically than those of the UK.

If such a situation of 'small events writ large' is the normal state of affairs in a small island economy, then erratic lurches would be very much the norm. Would not one then expect residents on such small economies to behave as actors and not just as victims, also taking whatever necessary and feasible initiatives to exploit such circumstances and not to just respond to them fatalistically and reactively? The minimisation of risk and the reduction of uncertainty in decision-making are fundamental strategies in economic behaviour (Brookfield, 1972: 167).

Of course, not everyone will be strategic, or strategic to the same extent. The disproportionate role of the state - as the employer of last resort; as a highly transparent, person-driven apparatus that dispenses 'cargo' and other benefits, especially to the politically sympathetic may lead some segments of the population to expect the state and politicians to provide deliverance from all evil; and political rhetoric may fuel such lofty expectations. Personal initiative may be actively discouraged and 'killed through kindness' (Hintjens, 1991: 51). But others will be more entrepreneurial. Indeed, most will be likely to combine whatever goods and 'welfare' they can appropriate from the state - including a steady and pensionable job for the lucky ones - with other sources of revenue, goods or services; deploying a repertoire of (formal/ informal) market, political, subsistence and reciprocity-based resources and mechanisms.

This disposition has been theorised, and of course, it is not restricted to small island economies; but while this theorisation has featured in various economic discussions that consider 'development traps' generally (e.g. De Soto, 1990; Easterly, 2001), its arguments have not filtered down enough to involve small island states and territories. We have a sustained but fragmented, critical scholarship on the concepts of 'economies of scope', 'handiness', 'flexible specialisation', 'polyvalency', 'occupational multiplicity', 'polydextrous and multifaceted competence', 'wearing many hats', being a Jack 
or Jill of all trades, and seeking to be a master or mistress of many, of combining employment with self-employment, of combining stints at home with stints overseas, in the contribution to overall economic security and success (Frucht, 1967; Comitas, 1973; Bennell and Oxenham, 1983; Putz, 1984: 16; Brock, 1988: 306; Farrugia and Attard, 1989; Fergus, 1991: 56). There is fair agreement that actors can respond by mutating and morphing, as they sense how the environment is shifting, or will shift. At the risk of echoing Charles Darwin, adaptation, dynamism and learning from ambient cues are the fabrics of (economic) life. But these considerations are often restricted to treatises of social anthropology, or character sketches, if not relegated to the status of just semi-serious and romantic anecdotes about island living. Moreover, while these may be critical and necessary behavioural traits, they may not be sufficient to achieve their intended economic goals, or to exploit their potential, without other supports (Poon, 1990).

\section{Intersectoral migration}

Meanwhile, strategic flexibility makes sense not only in a context of turbulence and insecurity; it is a rewarding disposition especially when there are options for 'migrating' - intersectorally and/or trans-territorially (Baldacchino and Bertram, 2009: 141). Trans-territorial migration has been extensively discussed and studied islands are 'intimately concerned' with migration, after all (e.g. King and Connell, 1999; Connell, 2007); the transnational orientation is at the heart of the Mlgration, Remittances, Aid and Bureaucracy (MIRAB) concept, whereby local island life is sustained largely by state aid and remittances from migrants overseas (Bertram and Watters, 1985). Moreover, there is increasing appreciation of cross-boundary and often dynamic and rotational migration patterns that challenge the imputed temporal and spatial fixities of 'homeness' (e.g. Vertovec, 2001; Duval, 2004; Baldacchino, 2006a). Somewhat surprisingly, however, there is hardly any similar scholarly appreciation of the phenomenon of intersectoral migration, with its own crossboundary dynamism, whereby specialisation is partial and deliberate. This is the field where strategic flexibility plays out.
There are some insights to this in the literature. Brookfield (1972: 167) talks about how peasant farmers within reach of an urban market might, at different times or at the same time, grow one or more cash crops for export, produce for the local market, grow food for their own subsistence and grow gifts for others to whom they are linked by reciprocal relationships. Moreover, they may work occasionally as stevedores or go away to town to seek employment; they may invest in a trade store or a vehicle; might assist the enterprise of others; and in turn receive aid for their own initiatives, apart from the looming option to migrate.

Brookfield (1972: 167-168) introduces us to Kawagl, a Chimbu subsistence farmer from Melanesia, to drive his point home. Over the course of a few years, Kawagl moves from growing coffee, to setting up a trade store, to engaging in wholesale business (which saw him buy a vehicle and employ a driver), then to 'go away for a few months' when he went bust and then returning to resume his trade store business. The story of islander life?

Such insights of 'muddling through' what are perceived as economic opportunities are not very common in the literature, although they are likely to be quite widespread in practice. I can single out similar personal portraits in the likes of Isaac Caines, from the Caribbean island state of St Kitts (profiled in Richardson, 1983: 54-55); and Marshy, a street vendor from Kingston, Jamaica (profiled in Wardle, 2002).

Public sector employment, or contract work, usually features in such plans. In the small European island state of Malta (my birth country), economist Delia (1994) has theorised a 'dual labour market', where most of the economically active population would, at an individual or household level, strive to combine a steady and pensionable public sector job with a private sector involvement that may pay better, while it lasts. Moreover, in high income tax regimes like Malta, there is an additional fiscal incentive to earn supplementary income that may not have to be registered for tax purposes: another attraction of private sector revenue.

Carnegie (1982: 12) describes 'a friend' who not only had a middle-management position with the public service but also had 'a steady income from furniture upholstery', was studying welding, wanted to learn refrigeration repair 
and was looking for an opportunity to go abroad to study agronomy. Is this truly an exceptional behaviour, or is it more prevalent than the literature may have us believe?

One can schematically compare the tenets and implications of the vulnerability approach with this, very different, 'strategic flexibility' variant, as exemplified in Table 1.

\section{Misplaced hyperspecialisation?}

A similar and complementary diversity can be glimpsed when we look at a small island economy from a 'top-down' perch. There may indeed be one or two leading industries contributing to GNP (and so suggesting critiques of dependency); but the concomitant accusation of hyperspecialisation is probably misplaced and unwarranted. This is because the small economy would also typically host a strong public sector, a construction industry, some rent-based economic activity, some aid and remittances from abroad, some tourism and hospitality-based services, some niche (perhaps unique) manufactures (including crafts), some banking and finance, some resource-based extractive industries (commercial fishing, crofting, farming, and mining), some subsistence activity (growing taro, raising chicken, harvesting coconuts, and artisanal fishing) and an amorphous informal economy that may thrive on barter, untraceable cash transactions or just casual reciprocity. As discussed earlier, the same players may have different stakes and presences in these different economic sectors, at the same time, or across time. The leading economic sector at a particular point in time would determine whether such an island economy would have been classified as a MIRAB (Bertram and Watters, 1985), or a SITE (small island tourist economy) (McElroy and Pearce, 2006) - the people and resource management, overseas engagement, finance and transportation (PROFIT) economy model is not based on such restrictions (Baldacchino, 2006b) (see Fig. 1). At the macro level, however, Bertram and Poirine (2007: 362) have concluded that 'the combination of offshore finance and highquality tourism stands out as the strategy of the most successful island economies'.

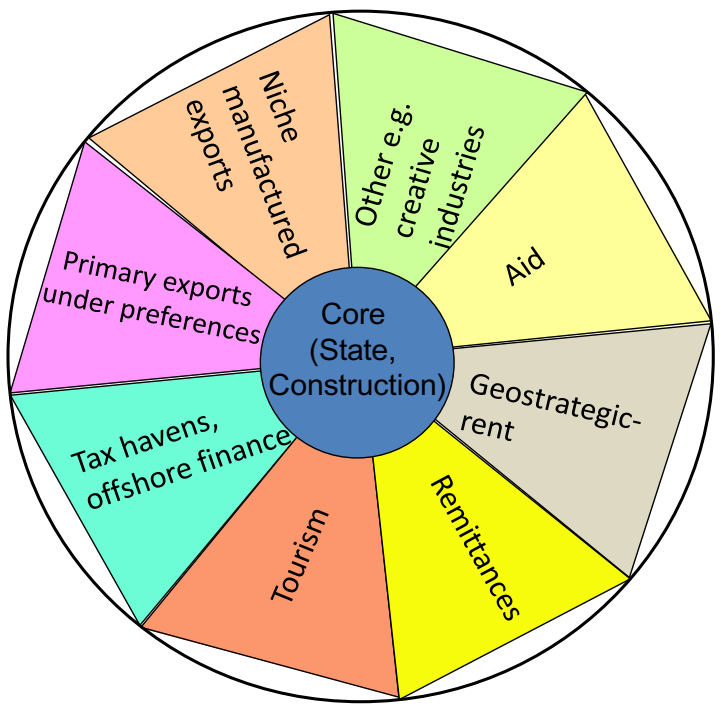

Figure 1. The main contributors to the gross national product of a small economy

Source: From Baldacchino and Bertram (2009: 155, Fig. 2).

Table 1. The 'strategic flexibility' versus 'vulnerability' approach to the performance of small economies: (adapted from Baldacchino and Bertram, 2009)

\begin{tabular}{|c|c|c|}
\hline Issue & Strategic flexibility approach & Vulnerability approach \\
\hline Grounding & 'Bottom-up', inductive & Prescriptive, 'top-down', deductive \\
\hline Tone & Optimistic, strategic & Pessimistic, deterministic \\
\hline Scope of vulnerability & Largely environmental & Wide-ranging \\
\hline $\begin{array}{l}\text { Smallness, isolation, islandness and } \\
\text { remoteness }\end{array}$ & Offer advantages and disadvantages & $\begin{array}{l}\text { Are inherent disadvantages (including } \\
\text { diseconomies of scale) }\end{array}$ \\
\hline $\begin{array}{l}\text { Comparison of smaller economies with } \\
\text { larger ones }\end{array}$ & Smaller economies can perform better & High resilience or 'paradoxes' \\
\hline Economic structure of small economies & Proactive behavioural adaptation & $\begin{array}{l}\text { Reactive response to exogenously set } \\
\text { price signals }\end{array}$ \\
\hline Capacity & Inherent & Needs to be 'built' and 'nurtured' \\
\hline Openness to international trac & Source of com & Source of weakness \\
\hline Dependence on transfers from abroad & Source of 'sustainable development' & Source of weakness \\
\hline
\end{tabular}


The diversity implicit in the range of clusters is often under-documented and their significance downplayed. And yet, at any point in time, these small economies already present a modicum of choices for players to consider, as they 'hedge their bets' in response to, or in anticipation of change. Petty self-employment combined with a public sector job can be very attractive, as would be a stint abroad, at the individual or household level.

A diachronic or longitudinal approach would reveal a different scenario. Given the volatility, openness and elasticity of small economies, the nature of these clusters, and their respective size, is bound to change in response to various political, fiscal and market forces, and is liable to do so suddenly, rapidly and totally. At their most striking transformations, 'MIRAB economies' have been heralded as having transited/ graduated to SITE/PROFIT economies: think Norfolk Island (Treadgold, 1999); or formerly more self-sustaining economies have had their ignominious descent to MIRAB status highlighted: think Nauru (Connell, 2006). But these are gross oversimplifications of more complex and nuanced behaviours, transitions and trends (Bertram, 2006). As these sectors expand or decline, at times quite dizzily, in their representation on national statistics tables and charts, the aggregated data of course disguise the interpretation of market signals and risks, and consequential decisions, some contradictory, of many actors. With each dramatic ebb of a 'growth pole', the socio-economy overall suffers painful dislocation: unemployment, debt and relative poverty may set in among the losers who may fight against their change of fortune but who eventually may be forced to resign themselves to accepting their fate and draw on state supports, fall back on familial buffers or informal economy activity (cashing in on rich, bonding social capital), switch opportunistically to the economic cluster that is perceived as the next winning horse, opt for temporary ex-i(s)le (Bongie, 1998) or pursue further education. Framing economic trends within a longer time scale has its rewards and surprises (e.g. Reenberg et al., 2008).

Within economics per se, we have a clutch of interesting studies that discuss and document the rise and fall of the fortunes of specific 'industries' in specific small island polities, real- ising how significant such industries have been in the context of small and islanded spaces; acknowledging the speed with which they tend to grow and assume commanding importance in the domestic sphere; and recognising the almost equal speed with which they just contract and disappear, with significant loss of employment. As with the geophysics of environmental events, these variations tend to be more rapid, more sudden and more total in their effects in smaller islanded economies. Nauru's function as an Australian offshore detention centre (a practice that seriously tests the notion of sovereignty) is one obvious and recent example (Penovic and Dastyari, 2007). Other suitable cases come to mind: whaling and Norfolk Island (Hoare, 1999: 85-87); pearl cultivation and nuclear testing in French Polynesia (Poirine, 2010; Haoatai and Monypenny, 2011); garment manufacturing in the Northern Marianas (McPhetres, 2011); bêche-de-mer in the Solomon Islands (Christensen, 2011); and kava and cut flowers from Fiji (Prasad and Raj, 2006; McGregor, 2007). The literature on 'the resource curse' and 'Dutch disease' is now a staple diet for small island economists (e.g. Ross, 1999). The environmental tale of many small islands, certainly following contact with the Western world, has indeed been a sequence of 'boom and bust' rapacious adventures.

\section{Managing 'boom and bust' scenarios}

How can we zoom out from the specifics of particular episodes of investment cycles that appear like 'loops on a roller coaster' (Christensen, 2011: 17)? How can we develop a better understanding of, first, how individuals and other corporate and political actors rush in to take up (or create) jobs, provide investment and ancillary services, or otherwise devise all the social, legal, regulatory, financial and other supports that these new opportunities may imply or require? And, second, how do these same actors move out, morph and reinvent themselves when such opportunities are no longer profitable, or are simply no longer there? After all, the life cycles of economic opportunity rarely align themselves perfectly with the life cycles of economic actors ... so somehow, such actors are riding multiple economic waves, successively and/or simultaneously, like 
so many intrepid ocean surfers... and hopefully coming out on top to face another day, and another wave. Surfing is indeed not just a useful metaphor but also a home-grown one in the world of islands: modern surfing was invented by Polynesians and popularised in the United States in the early 1900s by Hawaiian surfers Duke Kahanamoku and George Freeth; in Hawai'i, surf tourism is a vibrant niche industry (Johnson and Orbach, 1986; Nelsen et al., 2007; Okihiro, 2008). And just as the surf zone has perhaps been liminal enough to resist colonial encroachment and Western hegemony, in much the same way, the metaphor could help us escape the debilitating paradigms of economic orthodoxy as they apply to small islands (Halekunihi Walker, 2007) - gripped as they currently are by another aquatic metaphor: sinking.

Can we therefore 'develop sensitivities towards strategies that will serve as buoys for future waves' (Ishiwata, 2002: 268)? The question is a pertinent one because this is not just a call to examine more holistically the coping responses and strategies of actors to change, as given, but also an invitation that appeals to our (presumably natural) craving for control, to be able to manage and plan for booms and opportunities; to create change that is seen as beneficial and relevant to local interests. The stuff of 'product development' is not necessarily confined to the flashy research and development offices and laboratories of multinational corporations, located far away in the science parks of the metropole. The 'how to' of change management is not the esoteric preserve of management gurus. In spite of the chronic powerlessness attributed to small economies, any such fatalism is misplaced and overplayed.

For one thing, we should not expect any such local innovation to be lavishly publicised. Small island citizens are extremely wary of, and sensitive to, local competition. They know very well that, if and when someone else senses what he or she may be up to, and follows suit, the profitability of the whole venture is quickly compromised. A 'tragedy-of-the-commons' scenario quickly sets in, and what had started off as a lucrative initiative may end up in ruin. For example:

Under cover of darkness . . . a few local fishermen from Luaniua developed as simple form of trawling net [to catch sea cucumber] ... the few men who developed the trawl kept it hidden, but soon other fishermen found out and adopted this new technology. [Within a year], almost all diving groups had replaced 'traditional' methods... with trawling ... [leading to] major social, ecological and economic changes. (Christensen, 2011: 14)

Nevertheless, there is much scope for understanding better how even a supposedly small, remote and resource poor island economy can 'smell' an investment opportunity. How does it provide the inputs necessary to generate foreign/local interest, investment and employment? How does 'optimal endogenous policy formulation and implementation' (Armstrong and Read, 1998: 213) actually pan out, and not just at the macro level (for governments) but also at the meso (or institutional) and micro (individual) levels as well?

The simple, and cynical, answer to such questions at the level of the state is perhaps graft. A small state is supple and flexible enough to make things happen fast; and the support and loyalty of just a few key individuals can be easily arranged by outsiders, over a wad of bank notes or the crediting of a bank account. It is, after all, so much easier for elected politicians to 'micromanage', involving themselves in the execution of their own policies, and supervising the allocation of any 'spoils', to the consternation of career civil servants (Richards, 1982: 155; Lowenthal, 1987; Rodhouse, 1987; Buker, 2005: 39). Such 'scandals' have happened, and will no doubt continue to do so, in small and not-so-small jurisdictions. (Perhaps they are more difficult to conceal in small island territories, where even the minutiae of what elsewhere would be private matters are subject to public consumption and media scrutiny.) But then, I for one would like to believe that not all investment opportunities unfold in this way. The suppleness and 'soft-state' arguments remain valid, graft or no graft; and one would hope that some significant investment deals have been struck by 'above-board' meetings between small island state ministers and corporate representatives.

\section{Smelling opportunity}

A more promising route may be suggested by the recent literature on resilience (e.g. Briguglio and 
Kisanga, 2004; Cooper and Shaw, 2009). While continuing to be couched as a response to ingrained vulnerability, resilience studies attribute some role to public policy in taking proactive measures meant to 'nurture' and 'build' domestic capacity for handling or mitigating external threats. Such 'capacity building' could easily extend to initiatives and programmes that make the management of change a more rewarding and profitable experience (puns intended). To be more specific, here are some questions that point in specific policy directions:

- Are there any particular educational pedagogies and curricula that facilitate the disposition of small island citizens to 'smell' entrepreneurial economic opportunity better and faster? Would these include an orientation towards 'flexible specialisation' and/or a postponement of educational and careerist specialisation until later years?

- Are there particular cultural traits, which may also be reflected in religious beliefs, that make individuals more or less likely to take economic risks and to face up better to the disappointment, and public shame, that could follow from business failure?

- To what extent does intrapreneurship - a canny ability to 'work the system' (Rule and Irwin, 1988) - develop opportunities for private sector investors to benefit from their innate knowledge of the machinery of government to contribute to economic growth?

- To what extent should the informal economy be recognised as an important cushion and pool of skill, labour and capital, rather than the site of semi-legal transactions that should also be 'brought out into the open' and taxed?

We know very well how keen and aggressive most small island jurisdictions are in ensuring that the avenues of migration for their citizens are open; many sub-national territories would see the thwarting of current migration outlets to attractive metropoles as one key obstacle on the road towards their full independence (Baldacchino and Milne, 2008). Should not such jurisdictions manifest at least as much enthusiasm and interest in supporting the enhancement of intersectoral migration? Or is this practice doomed to continue and persevere in spite of, rather than thanks to, the proactive policies of small island governments?

\section{In my defence}

Of course, I know that I am liable to stand accused of being both mock heroic and naively romantic. Ocean surfers are puny and fragile in contrast to the awesome fury, power and swell of the ocean; accidents, at times fatal, can and do happen. High population growth, urbanisation, ethnic conflict, poverty and chronic (especially youth) unemployment are real threats to liveability in the insular Pacific. But consider the thesis of this paper to be another way of analysing the resilience of small island economies, without, however, necessarily representing this 'capacity' as a response to chronic vulnerability. As a small island state citizen myself, I continue to believe in empowerment and human agency. Necessity remains the mother of invention. And I prefer calling the proverbial glass half full. 'Choice' is not purely a matter of fate or historical circumstance but also an outcome of creative performance, of playful and contingent flirtation with chance - whether rational, thought out and strategic, or simply spontaneous, whimsical and serendipitous. The clarion call of this paper is precisely to grapple with this flirtation: taking it upstream (by conceptualising it) or downstream (by looking more carefully at its unfolding in micro, institutional and macro decision-making contexts). These 'change-management' antics may be messy and hard to classify, but they are closer representations of what actually takes place. They are also better explanations of my own life as an economic actor, and presumably of the lives of many others.

Social scientists across various disciplines have some obligation to acknowledge these dynamics and to give intersectoral migration at least as much importance and credence as its extra-territorial sibling in the pursuit of a more comprehensive understanding of small island life.

\section{Conclusion: Crashing over boundaries}

Echoing Peter Katzenstein (1985: 211, 2003: 30), small states and territories are not likely to find a solution to the problem of change, appealing though that will always be. Rather, they manifest ways of living and coping with change, as well as managing change. Their dynamic flexibility and 'rapid response capability' (Bertram and Poirine, 
2007: 333) at multiple levels is both a default/ reactive and strategic/proactive disposition to opportunity; such capacities and skills are all the more smart to have and to hone when there is a precarious dependency on one or two economic activities at a national level.

Without such an appreciation, one is easily gripped by a 'paradise-lost' paradigm that continues to await an inevitable tragic end. 'The end ever nigh' wrote John Connell (1988) about Pitcairn, the Pacific's smallest jurisdiction. More than two decades and a stormy child sex abuse scandal later, the Pitcairnese have not turned off the lights yet; they continue to issue postage stamps, a key export item. The best that some observers can do, it seems, is to consider such a skill set within the rubric of an unimpressive 'muddling on', and high levels of distasteful 'dependency' (Duncan and Gilling, 2005: 8, 22).

The nurturing and deployment of this skill set (read the surfer), along with a suite of suitable policy supports (read the surf board), is crucial for providing a fuller explanation for the resilience, liveability and very existence of small island economies, as well as for the vital relationship that these economies maintain with temporary or permanent migration:

As fantastic as it may be, to someone who surfs it makes perfect sense because surfing is by its very nature an anticipatory and optimistic endeavour: the next swell, the next wave, the next ride. (Ishiwata, 2002: 269)

\section{Acknowledgements}

My thanks to Warwick Murray and the members of the Editorial Board of Asia Pacific Viewpoint for inviting me to deliver the 2011 annual APV Lecture at Victoria University in Wellington, New Zealand, on 7 April 2011. This paper is based on that address and has benefited from various critical comments received on that occasion. The first rough draft of this paper was developed while serving as visiting professor at the School of Geography and Environmental Sciences, University of Tasmania, Australia. I also acknowledge the intellectual contribution of Geoff Bertram and Joseph Vella Bonnici in nurturing various ideas contained in this paper. The usual disclaimers apply.

\section{References}

Alesina, A. and E. Spolaore (2003) The size of nations. Cambridge, Massachusetts: MIT Press.

Armstrong, H.W. and R. Read (1998) The international political economy of microstates: An overview. Paper Presented at the Islands of the World V Conference, Mauritius, University of Mauritius.

Armstrong, H.W. and R. Read (2003) The determinants of economic growth in small states, The Round Table: Commonwealth Journal of International Affairs 92(368): 99-124.

Armstrong, H.W. and R. Read (2004) Small states and island states: Implications of size, location and isolation for prosperity, in J. Poot (ed.), On the edge of the global economy, pp. 191-223. Cheltenham: Edward Elgar.

Baldacchino, G. (1993) Bursting the bubble: The pseudodevelopment strategies of microstates, Development and Change 24(1): 29-51.

Baldacchino, G. (2006a) The brain rotation and brain diffusion strategies of small islanders: Considering 'movement' in lieu of 'place', Globalisation, Societies and Education 4(1): 143-154.

Baldacchino, G. (2006b) Managing the hinterland beyond: Two, ideal-type strategies of economic development for small island territories, Asia Pacific Viewpoint 47(1): 45-60.

Baldacchino, G. (2010) Island enclaves: Offshoring, creative governance and subnational island jurisdictions. Montreal: McGill-Queen's University Press.

Baldacchino, G. and G. Bertram (2009) The beak of the finch: Insights into the economic development of small, often island, economies, The Round Table: Commonwealth Journal of International Affairs 98(401): 141-160.

Baldacchino, G. and D. Milne (eds.) (2008) The case for non-sovereignty: Lessons from sub-national island jurisdictions. London: Routledge.

Bates, D.C. (2002) Environmental refugees? Classifying human migrations caused by environmental change, Population and Environment 23(5): 465-477.

Bennell, P. and J. Oxenham (1983) Skills and qualifications in small island states, Labour and Society 8(1): 3-38.

Bertram, G. (2006) Introduction: The MIRAB model in the 21st century, in G. Bertram (ed.), Asia Pacific Viewpoint, Vol. 47(1), pp. 1-13.

Bertram, G. and B. Poirine (2007) Island political economy, in G. Baldacchino (ed.), A world of islands: An island studies reader, pp. 323-378. Charlottetown: Institute of Island Studies, Luqa and Malta: Agenda Academic.

Bertram, G. and R.E. Watters (1985) The MIRAB economy in South Pacific microstates, Pacific Viewpoint 26(3): 497-519.

Bongie, C. (1998) Islands and exiles: The Creole identities of post/colonial literature. Stanford, California: Stanford University Press.

Bowen-Jones, H. (1972) Malta: An essay in historical ecology, in $\mathrm{H}$. Bowen-Jones (ed.), Human ecology in the Commonwealth, pp. 59-74. London: Charles Knight.

Briguglio, L. (1995) Small island developing states and their economic vulnerabilities, World Development 23(9): 1615-1632. 
Briguglio, L. and E.J. Kisanga (2004) Economic vulnerability and resilience of small states. London: Commonwealth Secretariat.

Brock, C. (1988) Education and national scale: The world of small states, Prospects 18(3): 303-314.

Brookfield, H.C. (1972) Colonialism, development and independence: The case of the Melanesian Islands in the South Pacific. Cambridge: Cambridge University Press.

Buker, P.E. (2005) The executive administrative style in Prince Edward Island: Managerial and spoils politics, in L. Bernier, K. Brownsley and M. Howlett (eds), Executive styles in Canada: Cabinet structures and leadership practices in Canadian government, pp. 111-131. Toronto, Ontario: University of Toronto Press.

Carnegie, C.V. (1982) Strategic flexibility in the West Indies: A social psychology of Caribbean migration, Caribbean Review 11(1): 10-13.

Carse, S. (1998) Sustaining small island development: The case of the Isle of Man, in G. Baldacchino and R. Greenwood (eds), Competing strategies of socioeconomic development for small islands, pp. 268-291. Charlottetown: Institute of Island Studies, University of Prince Edward Island.

Christensen, A.E. (2011) Marine gold and atoll livelihoods: The rise and fall of the bêche-de-mer trade on Ontong Java, Solomon Islands, Natural Resources Forum 35(1): 9-20.

Comitas, L. (1973) Occupational multiplicity in rural Jamaica, in L. Comitas and D. Lowenthal (eds.), Work and family life: West Indian perspectives, pp. 157-173. New York: Anchor Press.

Connell, J. (1988) The end ever nigh: Contemporary population change on Pitcairn Island, Geo Journal 6(1): 193-200.

Connell, J. (2006) Nauru: The first Pacific failed state? The Round Table: Commonwealth Journal of International Affairs 95(383): 47-63.

Connell, J. (2007) Island migration, in G. Baldacchino (ed.), A world of islands: An islands studies reader, pp. 455482. Charlottetown: Institute of Island Studies, Luqa and Malta: Agenda Academic.

Cooper, A.F. and T. Shaw (eds.) (2009) The diplomacies of small states: Between vulnerability and resilience. New York: Palgrave Macmillan.

De Soto, H. (1990) The other path: The invisible revolution in the Third World. New York: Perennial Library.

Delia, E.P. (1994) A labour market in transition, in R.G. Sultana and G. Baldacchino (eds.), Maltese society: $A$ sociological inquiry, pp. 450-475. Malta: Mireva.

Dommen, E.C. (1980) Some distinguishing characteristics of island states, World Development 8(12): 931944.

Duncan, R. and J. Gilling (2005) Pacific island countries: Analytical report for the white paper on Australia's aid program. Canberra: Australian Government.

Duval, D.T. (2004) Conceptualising return visits: A transnational perspective, in T. Coles and D. Timothy (eds.), Tourism, diasporas and space: Travels to promised lands, pp. 50-61. London: Routledge.

Easterly, W. (2001) The elusive quest for growth. Economists' adventures and misadventures in the tropics. Cambridge, Massachusetts: MIT Press.
Easterly, W. and A.C. Kraay (2000) Small states, small problems? Income, growth and volatility in small states, World Development 28(11): 2013-2027.

Farrugia, C.J. and P.A. Attard (1989) The multifunctional administrator. London: Commonwealth Secretariat.

Fergus, H.E. (1991) The challenge of educational reform in microstates: A case study of the Organisation of Eastern Caribbean States, Prospects 21(4): 561-571.

Frucht, R. (1967) A Caribbean social type: Neither peasant nor proletarian, Social and Economic Studies 16(2): 295-300.

Halekunihi Walker, I. (2007) Hui Nalu, beachboys, and the surfing boarder-lands of Hawai'i, Contemporary Pacific 20(1): 89-113.

Haoatai, H. and R. Monypenny (2011) Export demand for Tahitian black pearls, Australasian Agribusiness Review 19(1): 1-15. Retrieved 30 September 2011, from Website: http://www.agrifood.info/review/2011/ Haoatai_Monypenny.pdf

Harden, S. (ed.) (1985) Small is dangerous: Micro-states in a macro-world. London: Frances Pinter.

Hintjens, H.M. (1991) France in the Caribbean, in P.K. Sutton (ed.), Europe and the Caribbean, pp. 37-70. London: Macmillan.

Hoare, M. (1999) Norfolk Island: A revised and enlarged history 1774-1998. Rockhampton, Queensland: Central Queensland University Press.

Ishiwata, E. (2002) Local motions: Surfing and the politics of wave sliding, Journal for Cultural Research 6(3): 257272.

Johnson, J.C. and M.K. Orbach (1986) The role of cultural context in the development of low-capital ocean leisure activities, Leisure Sciences 8(3): 319-339.

Katzenstein, P.J. (1985) Small states in world markets: Industrial policy in Europe. Ithaca, New York: Cornell University Press.

Katzenstein, P.J. (2003) Small states' and small states revisited, New Political Economy 8(1): 9-30.

King, R. and J. Connell (eds) (1999) Small worlds, global lives: Islands and migration. London: Pinter.

Lowenthal, D. (1987) Social issues, in C.G. Clarke and T. Payne (eds.), Politics, security and development in small states, pp. 26-49. London: Allen and Unwin.

McElroy, J.L. and K.B. Pearce (2006) The advantages of political affiliation: Dependent and independent small island profiles, The Round Table: Commonwealth Journal of International Affairs 95(386): 529-540.

McGregor, A.M. (2007) The export of horticultural and high-value agricultural products, Pacific Economic Bulletin 22(3): 81-99.

McPhetres, S.F. (2011) Commonwealth of the Northern Mariana Islands, Contemporary Pacific 23(1): 190198.

Mead, M. (1930/1973) Growing up in New Guinea. Harmondsworth: Penguin.

Nath, S., J.L. Roberts and Y.N. Madhoo (eds.) (2010) Saving small island developing states: Environmental and natural resource challenges. London: Commonwealth Secretariat.

Nelsen, C., L. Pendleton and R. Vaughn (2007) A socioeconomic study of surfers at trestles beach, Shore and Beach 75(4): 32-37. 


\section{G. Baldacchino}

Okihiro, G.Y. (2008) Island world: A history of Hawai'i and the United States. Berkeley, California: University of California Press.

Penovic, T. and A. Dastyari (2007) Boatloads of incongruity: The evolution of Australia's offshore processing regime, Australian Journal of Human Rights 13(33): 1-29. Retrieved 30 September 2011, from Website: http://papers.ssrn.com/sol3/papers.cfm?abstract_id= 1407403\#\#

Poirine, B. (1998) Should we hate or love MIRAB? The Contemporary Pacific 10(1): 65-105.

Poirine, B. (2010) The economy of French Polynesia: Past, present and future, Pacific Economic Bulletin 25(1): 24-34. Retrieved 30 September 2011, from Website: http://peb.anu.edu.au/pdf/PEB25_1_Poirine.pdf

Poon, A. (1990) Flexible specialization and small size: The case of Caribbean tourism, World Development 18(1): 109-123.

Prasad, N. and S. Raj (2006) The perils of unmanaged export growth: The case of kava in Fiji, Journal of Small Business and Entrepreneurship 19(4): 381394.

Putz, G. (1984) On islanders, Island Journal (Maine), 1(1): 26-29.

Reenberg, A., T. Birch-Thomsen, O. Mertz, B. Fog and S. Christiansen (2008) Adaptation of human coping strategies in a small island society in the South-West Pacific: 50 years of change in the coupled humanenvironment system of Bellona, Solomon Islands, Human Ecology 36(6): 807-819.
Richards, J. (1982) Politics in small, independent communities: Conflict or consensus? Journal of Commonwealth and Comparative Politics 20(2): 155-171.

Richardson, B.C. (1983) Caribbean migrants: Environment and human survival in St Kitts and Nevis. Knoxville, Tennessee: University of Tennessee Press.

Rodhouse, J. (1987) Problems of policy and development, in K. Bacchus and C. Brock (eds.), The challenge of scale: Educational development in the small states of the Commonwealth, pp. 19-24. London: Commonwealth Secretariat.

Ross, M.L. (1999) The political economy of the resource curse, World Politics 51(2): 297-322.

Rule, E.G. and D. Irwin (1988) Fostering intrapreneurship: The new competitive edge, Journal of Business Strategy 9(3): 44-47.

Tisdell, C.A. (1993) Project appraisal, the environment and sustainability for small islands, World Development 21(2): 213-219.

Treadgold, M.L. (1999) Breaking out of the MIRAB mould: Historical evidence from Norfolk Island, Asia Pacific Viewpoint 40(3): 235-249.

Vertovec, S. (2001) Transnationalism and identity, Journal of Ethnic and Migration Studies 27(4): 573-582.

Wardle, H. (2002) Marshy and friends: Informality, deformalization and the West Indian Island experience, Social Identities 8(2): 255-270.

Winters, L.A. and P. Martins (2004) When comparative advantage is not enough: Business costs in small remote economies, World Trade Review 3(3): 347-383. 